\title{
MEMBANGUN JARINGAN USAHA BAGI USAHA KECIL DAN MENENGAH DI MASA PANDEMI
}

\author{
Hamzah Fansuri Yusuf ${ }^{1}$, Yani Dahliani ${ }^{2}$, Wiwik Fitria Ningsih ${ }^{3}$ \\ STIE Mandala, Jember \\ Email: hamzah@stie-mandala.ac.id 1
}

\begin{abstract}
Abstrak
Pembangunan ekonomi yang bertumpu pada segelintir orang atau kelompok untuk mengejar pertumbuhan yang tinggi dengan harapan terjadinya penetesan ke bawah tidak pernah terwujudkan. Justru sebaliknya yang terjadi, kemiskinan dan tingkat pengangguran bertambah terus setiap tahun. Sektor usaha kecil dan menengah yang diakui dunia mampu menjadi penopang ekonomi nasional tidak terperhatikan selama ini dan semakin tersisih dalam persaingan. Pandemi yang menempa bangsa ini, membuat memberikan perhatian pada UMKM. Namun sudahkah kita betul-betul memberikan perhatian yang penuh pada UMKM. Inilah yang harus diwujudkan terlebih lagi menghadapi tantangan yang semakin berat ke depan dalam era globalisasi dan otonomi daerah. Usaha kecil dan menengah harus mampu bersaing dengan pelaku ekonomi lainnya, baik di dalam dan luar negeri.

Kata Kunci: UMKM, Pandemi, Jaringan
\end{abstract}

\section{PENDAHULUAN}

Pemberdayaan usaha mikro, kecil dan menengah (UMKM) dan Koperasi merupakan langkah yang strategis dalam meningkatkan dan memperkuat dasar kehidupan perekonomian dari sebagian terbesar rakyat Indonesia, khususnya melalui penyediaan lapangan kerja dan mengurangi kesenjangan dan tingkat kemiskinan. Dengan demikian upaya untuk memberdayakan UMKM harus terencana, sistematis dan menyeluruh baik pada tataran makro, meso dan mikro yang meliputi (1) penciptaan iklim usaha dalam rangka membuka kesempatan berusaha seluas-luasnya, serta menjamin kepastian usaha disertai adanya efisiensi ekonomi; (2) pengembangan sistem pendukung usaha bagi UMKM untuk meningkatkan akses kepada sumber daya produktif sehingga dapat memanfaatkan kesempatan yang terbuka dan potensi sumber daya, terutama sumber daya lokal yang tersedia; (3) pengembangan kewirausahaan dan keunggulan kompetitif usaha kecil dan menengah (UKM); dan (4) pemberdayaan usaha skala mikro untuk meningkatkan pendapatan masyarakat yang bergerak dalam kegiatan usaha ekonomi di sektor informal yang berskala usaha mikro, terutama yang masih berstatus keluarga miskin. Selain itu, peningkatan kualitas koperasi untuk berkembang secara sehat sesuai dengan jati dirinya dan membangun efisiensi kolektif terutama bagi pengusaha mikro dan kecil.

Perkembangan peran usaha mikro, kecil, dan menengah (UMKM) yang besar ditunjukkan oleh jumlah unit usaha dan pengusaha, serta kontribusinya terhadap pendapatan nasional, dan penyediaan lapangan kerja. Pada tahun 2003, persentase jumlah UMKM sebesar 99,9 persen dari seluruh unit usaha, yang terdiri dari usaha menengah sebanyak 62,0 ribu unit usaha dan jumlah usaha kecil sebanyak 42,3 juta unit usaha yang sebagian terbesarnya berupa 
usaha skala mikro. UMKM telah menyerap lebih dari 79,0 juta tenaga kerja atau 99,5 persen dari jumlah tenaga kerja pada tahun 2004 jumlah UMKM diperkirakan telah melampaui 44 juta unit. Jumlah tenaga kerja ini meningkat rata-rata sebesar 3,10 persen per tahunnya dari posisi tahun 2000. Kontribusi UMKM dalam PDB pada tahun 2003 adalah sebesar 56,7 persen dari total PDB nasional, naik dari 54,5 persen pada tahun 2000. Sementara itu pada tahun 2003, jumlah koperasi sebanyak 123 ribu unit dengan jumlah anggota sebanyak 27.283 ribu orang, atau meningkat masing-masing 11,8 persen dan 15,4 persen dari akhir tahun 2001.

Berbagai hasil pelaksanaan kebijakan, program dan kegiatan pemberdayaan koperasi dan UMKM pada tahun 2004 dan 2005, antara lain ditunjukkan oleh tersusunnya berbagai rancangan peraturan perundangan, antara lain RUU tentang penjaminan kredit UMKM dan RUU tentang subkontrak, RUU tentang perkreditan perbankan bagi UMKM, RPP tentang KSP, tersusunnya konsep pembentukan biro informasi kredit Indonesia, berkembangnya pelaksanaan unit pelayanan satu atap di berbagai kabupaten/kota dan terbentuknya forum lintas pelaku pemberdayaan UKM di daerah, terselenggaranya bantuan sertifikasi hak atas tanah kepada lebih dari 40 ribu pengusaha mikro dan kecil di 24 propinsi, berkembangnya jaringan layanan pengembangan usaha oleh $B D S$ providers di daerah disertai terbentuknya asosiasi $B D S$ providers Indonesia, meningkatnya kemampuan permodalan sekitar 1.500 unit KSP/USP di 416 kabupaten/kota termasuk KSP di sektor agribisnis, terbentuknya pusat promosi produk koperasi dan UMKM, serta dikembangkannya sistem insentif pengembangan UMKM berorientasi ekspor dan berbasis teknologi di bidang agroindustri. Hasil-hasil tersebut, telah mendorong peningkatan peran koperasi dan UMKM terhadap perluasan penyediaan lapangan kerja, pertumbuhan ekonomi, dan pemerataan peningkatan pendapatan.

Perkembangan UMKM yang meningkat dari segi kuantitas tersebut belum diimbangi oleh meratanya peningkatan kualitas UMKM. Permasalahan klasik yang dihadapi yaitu rendahnya produktivitas. Keadaan ini disebabkan oleh masalah internal yang dihadapi UMKM yaitu: rendahnya kualitas SDM UMKM dalam manajemen, organisasi, penguasaan teknologi, dan pemasaran, lemahnya kewirausahaan dari para pelaku UMKM, dan terbatasnya akses UMKM terhadap permodalan, informasi, teknologi dan pasar, serta faktor produksi lainnya. Sedangkan masalah eksternal yang dihadapi oleh UMKM diantaranya adalah besarnya biaya transaksi akibat iklim usaha yang kurang mendukung dan kelangkaan bahan baku. Juga yang menyangkut perolehan legalitas formal yang hingga saat ini masih merupakan persoalan mendasar bagi UMKM di Indonesia, menyusul tingginya biaya yang harus dikeluarkan dalam pengurusan perizinan. Sementara itu, kurangnya pemahaman tentang koperasi sebagai badan usaha yang memiliki struktur kelembagaan (struktur organisasi, struktur kekuasaan, dan struktur insentif) yang unik/khas dibandingkan badan usaha lainnya, serta kurang memasyarakatnya informasi tentang praktek-praktek berkoperasi yang benar (best practices) telah menyebabkan rendahnya kualitas kelembagaan dan organisasi koperasi. Bersamaan dengan masalah tersebut, koperasi dan UMKM juga menghadapi tantangan terutama yang ditimbulkan oleh pesatnya perkembangan globalisasi ekonomi dan liberalisasi perdagangan bersamaan dengan cepatnya tingkat kemajuan teknologi.

Secara umum, perkembangan koperasi dan UMKM diperkirakan masih akan menghadapi masalah mendasar dan tantangan sebagaimana dengan tahun sebelumnya, yaitu rendahnya 
produktivitas, terbatasnya akses kepada sumber daya produktif, rendahnya kualitas kelembagaan dan organisasi koperasi, dan tertinggalnya kinerja koperasi.

\section{HASIL DAN PEMBAHASAN}

\section{a. MEMBANGUN JEJARING UMKM}

Pemikiran-pemikiran besar para pemimpin bangsa kita yang tertuang dalam konstitusi,diantaranya, belum banyak yang sempat kita wujudkan. Salah satu diantaranya adalah amanat yang tercantum dalam kalimat terakhir Pembukaan UUD'45 yang berbunyi: “.....serta dengan mewujudkan suatu keadilan sosial bagi seluruh rakyat Indonesia". Selain itu, kita juga belum menjalankan dengan baik amanat Pasal 33 daripada UUD'45, jika disimak apa yang telah dilakukan oleh pemerintah selama ini, sejak era Orde Baru, di bawah pemerintahan Presiden Soeharto, sampai saat ini di bawah Susilo Bambang Yudhoyono; tampak sekali upaya mewujudkan cita-cita tersebut sangat jauh dari harapan. Bukan kesejahteraan dan kemakmuran yang berhasil kita wujudkan, justru sebaliknya yang terjadi. Ketimpangan sosial dan ekonomi semakin besar. Yang kaya semakin kaya dan yang miskin semakin miskin. Tingkat pengangguran juga semakin bertambah. Ketergantungan pada bantuan luar negeri, dan sekarang juga dalam negeri dalam bentuk SPN rasanya sulit dilepaskan. Ini semua terjadi karena salah urus di dalam penyusunan dan melaksanaan kebijakan dan program pembangunan yang dilaksanakan selama ini.

Pembangunan ekonomi yang bertumpu pada segelintir orang atau kelompok untuk mengejar pertumbuhan yang tinggi dengan harapan terjadinya penetesan ke bawah tidak pernah terwujudkan. Justru sebaliknya yang terjadi, kemiskinan dan tingkat pengangguran bertambah terus setiap tahun. Sektor usaha kecil dan menengah yang diakui dunia mampu menjadi penopang ekonomi nasional tidak terperhatikan selama ini dan semakin tersisih dalam persaingan. Krisis yang menerpa bangsa ini pada pertengahan tahun 1997, membuat memberikan perhatian pada UMKM. Pertanyaannya sudahkah kita betul-betul memberikan perhatian yang penuh pada UMKM? Inilah yang harus diwujudkan terlebih lagi menghadapi tantangan yang semakin berat ke depan dalam era globalisasi dan otonomi daerah. Usaha kecil dan menengah harus mampu bersaing dengan pelaku ekonomi lainnya, baik di dalam dan luar negeri.

Salah satu upaya yang dapat dilakukan untuk meningkatkan daya saing adalah pengembangan jeringan usaha. Melalui jeringan usaha ini akan terjadi penguatan posisi tawar para pelaku bisnis dalam mengembangkan bisnisnya.

c. Mengapa Jaringan Usaha.

Harus disadari bahwa keberadaan usaha mikro, kecil dan menengah (UMKM) sebagian integral dari pembangunan nasional tidak bisa diabaikan. Krisis moneter yang berawal pada pertengahan Juli1997 dan merembet pada Krisis ekonomi, politik dan sosial atau lebih dikenal dengan nama krisis multidimensi telah membawa berkah tersendiri bagi kehidupan UMKM. Kalau di masa Orde Baru kehadiran UKM sering dipinggirkan, kini telah diakui oleh semua pihak, khususnya pemerintah, untuk mendapatkan perhatian khusus. Kebijakan masa lalu yang 
beroientasi untuk mengejar pertumbuhan ekonomi tanpa memperhatikan pemerataan hasil-hasil pembangunan telah dirasakan keliru. Orientasi pada pertumbuhan tersebut, ternyata tidak berhasil mengurangi jurang kesenjangan antara yang kaya dengan yang miskin, antara wilayah barat dengan wilayah timur atau antara pelaku bisnis kecil - baca pengusaha mikro kecil dan menengah dengan pelaku bisnis besar-baca konglomerat.

Kisah masa lalu dan krisis multidimensi yang terjadi selama ini telah membawa perubahan mendasar pada paradigma pembangunan nasional. Pemusatan ekonomi tidak lagi menjadi prioritas; justru sebaliknya kesempatan yang seluas-luasnya harus diberikan kepada semuanya tanpa harus memandang suku, agama, ras, dan golongan. Ini berarti kesempatan bagi berkembangnya UMKM semakin terbuka. UMKM yang menguasai 99,99\% dari seluruh usaha nasional harus diberdayakan agar mampu berperan lebih besar dalam perekonomian nasional. Mereka, yang kini jumlahnya besar tersebut mampu menyerap lebih dari $99 \%$ angkatan kerja saat ini harus mampu memberikan kontribusi yang besar juga dalam ekspor dan Produk Domestik Bruto (PDB). Saat ini mereka masih menyumbang tidak lebih dari $20 \%$ dalam ekspor dan 59.36\% dalam PDB. Kalau dilihat dari perjalanan negara maju seperti Amerika Serikat, Jepang, Italia dan Taiwan yang sebagian besar ekonominya di dukung oleh UMKM, maka kita harus berupaya mengembangkan UKM agar mampu berkiprah lebih besar dalam perekonomian nasional.

Pada negara-negara maju tersebut diatas, peran UMKMnya sudah melebihi peran Usaha Besar. Dalam ekspor, misalnya sudah lebih dari 55\% merupakan kontribusi UMKM di negaranegara tersebut. Bahkan di Italia, peran UKM dalam ekspor sudah mencapai lebih dari $75 \%$.

Pertanyaan yang mungkin muncul adalah apakah hal ini bisa dilakukan oleh UMKM Indonesia? Untuk menjawab pertanyaan tersebut, kita harus optimis karena kita memiliki potensi sangat besar untuk dikembangkan oleh UMKM. UMKM harus didorong mengembangkan usahanya dengan berdasarkan sumberdaya lokal dan berorientasi ekspor. Dengan strategi pengembangan usaha berorintasi ekspor dengan menggali dari potensi sumberdaya lokal yang tersedia, khususnya pada sektor agrobisnis/agroindustri termasuk kelautan dan perikanan berarti kita telah mengembangkan "comparative advantage" untuk dikembangkan menjadi "competitive advantage". Kalau hal ini berhasil diwujudkan, maka UMKM kita akan mampu bersaing menghadapi pasar dan investasi bebas pada era global mendatang.

Untuk lebih meningkatkan daya saing UKM memasuki pasar global tersebut, pengembangan jaringan usaha antara UMKM, atau antara UMKM dengan usaha besar di dalam negeri maupun di luar negeri perlu terus dikembangkan. Upaya pengembangan jaringan usaha ini sangat penting dan strategis terutama untuk meningkatkan cakupan ekonomi, efisiensi, pengelolaan bisnis yang efisien, dan memperluas pangsa pasar. Dengan demikian UMKM akan memiliki kekuatan untuk bersaing dengan pelaku bisnis lainnya, baik dari dalam maupun luar 
negeri.

\section{d. Beberapa Konsepsi Jaringan Usaha}

Keberhasilan pengembangan UMKM di beberapa negara maju diantaranya karena jaringan usahanya (business networks) berkembang dengan baik. Ambil contoh di Taiwan, misalnya, ada dua konsep yang dikembangkan, yaitu: (a) untuk sektor industri dikenal dengan "satelite factory system" dan (b) untuk sektor non indutri jaringan usaha yang dikembangkan disebut "cooperative exchange program". Konsep satelite factory system (John C.I NI, 1997) mengungkapkan identik dengan pola sub kontrak sebagaimana berkembang pada industri otomotif di Jepang. Industri-industri besar melakukan sub kontrak beberapa komponen yang dikerjakan oleh industri kecil dan menengah. Dalam kaitan ini, industri besar hanya memproduksi bagian-bagian penting dan merakit produk yang dihasilkan. Di Taiwan, industriindustri yang mengembangkan sistem setelit antara lain industri perakitan mobil, indutri elektronik (ACER, SONY, Motorolla, dll), dan industri mesin pesawat (Thunder Tiger).

Konsep cooperative exchange program, merupakan forum kerjasama informasi dan pengalaman dalam pengembangan usaha. Jaringan usaha seperti ini dilakukan secara multi sektoral. Misalnya, UMKM yang bergerak di sektor pertanian atau kelautan dan perikanan melakukan kerjasama dengan sektor perdagangan dan jasa. Kerjasama usaha ketiga sektor ini bermanfaat untuk memperoleh informasi harga atau informasi komoditi yang memiliki prospek cerah ke depan. Di samping tentunya untuk memasarkan produk yang dihasilkan.

Di Australia (John Dean, 1997) mengungkapkan pengalaman pengembangan jaringan usaha yang dirintis melalui proyek program network antara tahun 1991 dan 1993. Pilot proyek jaringan usaha di Australia dilaksanakan oleh "the National Industry Extension Service (NIES)" yaitu suatu joint venture antara pemerintah commonwealth dengan delapan negara bagian teritori. Dari pilot proyek tersebut, menurut John Dean dapat diklasifikasikan dua konsepsi jaringan usaha yang berkembang, yaitu "hard" dan "soft" networks. Hard networks merupakan jaringan usaha yang betul-betul terjadi secara solid dalam mengembangkan usaha. Sedangkan soft networks lebih kearah jaringan usaha informal yang pada dasarnya untuk saling tukarmenukar informasi. Lebih jauh John Dean mengungkapkan bahwa jaringan usaha hendaknya jangan dipaksakan, tetapi pemerintah tetap memberikan arahan dan para pelaku bisnis diberikan kesempatan untuk melakukan kerjasama usaha atas prakarsanya sendiri. Beberapa contoh pengembangan jaringan usaha yang berhasil di Australia adalah :

1. Asia Pacific Design Group. Jaringan usaha ini dibentuk oleh 11 perusahaan yang bergerak dalam jasa konsultasi untuk seluruh aspek bangunan dan konstruksi 
2. ATVC. ATVC adalah Automotive Trim and Upholstrey Contractors Network. Dimana 8 perusahaan membentuk jaringan usaha untuk memenangkan kontrak-kontrak tender pemasangan rel untuk Trim, dimana yang selama ini selalu dimenangkan oleh Bridgestone dari Jepang atau Amerika Utara .

3. Daplar. Daplar merupakan jaringan kerjasama dari 4 perusahaan pembuat kabinet dan penyambungan yang memproduksi kitchen set dan kamar mandi. Jaringan usaha ini mampu memproduksi rangka-rangka rumah yang "knocked down"

4. Ambulances to Asia. Jaringan ini menyediakan paket ambulances siap pakai untuk layanan medis guna memenuhi permintaan di pasaran Asia.

5. Oz Electronics Manufacturing. Jaringan tersebut adalah kerjasama usaha antara 3 (tiga ) perusahaan elektronik kecil dimana menghadapi masalah yang sama yaitu biaya komponen perusahaan tersebut yang tinggi yang dibutuhkan. Tanpa jaringan ini tampaknya mereka tidak mungkin bisa bertahan dalam menghadapi biaya tinggi tersebut.

Selain konsepsi jaringan usaha tersebut diatas, menurut pendapat C. Richard Hatch (2000) dalam makalah yang disampaikan pada lokakarya di Manila yaitu "The ADB/OECD Workshop on SME Financing in Asia" mengemukakan beberapa konsep jaringan usaha, yang secara umum terdapat 4 type jaringan yang berbeda, antara lain.

1.Jaringan yang berkonfigurasikan kembali agar rantai perusahaan bermakna, untuk membuat scope bisnis yang ekonomis. Beberapa contoh jaringan usaha ini adalah di Denmark, 11 pembuat pakaian jadi membentuk Christian Dior Line (CD-Line) untuk menggali kemampuan mereka dalam memenuhi perlengkapan untuk memproduksi jas, baju, assesoris dan retsleting. Sehingga perusahaan-perusahaan yang membentuk jaringan tersebut mampu membangun "image clothing" bagi perusahaan besar Eropa

2. Jaringan yang meningkatkan efisiensi internal, memampukan UMKM akan menyadari pentingnya skala ekonomi. Salah satu contoh yang berhasil mengenai hal ini adalah proyek perusahaan penghasil alat-alat pertanian di bagian Utara Argentina dekat Propinsi Mato Grasso di Brasilia. Jaringan tersebut dibentuk oleh karena adanya kondisi lahan yang mampu, mereka ingin mengembangkan pertanian yang efektif. Mereka mengembangkan konsep pemasaran bersama dan percobaan rekayasa desain untuk mengurangi integrasi vertical agar proses produksi lebih efisien. Jaringan ini secara perlahan berhasil menjadi spesialisasi manufaktur yang besar, meningkatkan sub-kontrak dan harga yang kompetitif

3.Jaringan untuk mengembangkan pengelolaan yang ekonomis. Secara teori ekonomi, usaha besar akan memperoleh keuntungan dengan pengelolaan yang ekonomis: adanya kemampuan menyebarkan biaya tinggi dari administrasi yang canggih, pembiayaan, dan aktivitas pemasaran 
melalui volume transaksi bisnis yang besar. Sementara itu produksi barang dan jasa yang didesentralisasi dapat menjadi efisien, manajer sekaligus pemilik yang terisolasi akan sama efektifnya dengan team pengelolaan yang tersebar. Beberapa contoh dari konsep ini adalah industri-industri kecil di Utara-Tengah Italia melakukan kerjasama dalam membiayai layanan "Business Development Services".

4.Jaringan untuk meningkatkan posisi tawar UMKM membantu akses pasar. Jelas sekali akan terjadi perluasan karena adanya peningkatan skala usaha. Jaringan yang luas berarti pemasaran juga meningkat.

\section{e. Bagaimana Membangun Jaringan Usaha}

Membangkitkan UMKM agar mau membangun jaringan usaha bukanlah pekerjaan yang mudah. Di Utara-Tengah Italia, yang merupakan epicentrum gerakan jaringan, telah merintisnya sejak awal tahun 1980 an. Sejak saat itulah awal bertumbuhnya jaringan usaha yang sukses di Emilia Romagna dan daerah sekitarnya. Keberhasilan tersebut telah memberikan perhatian bagi para cendikiawan dari kawasan Eropa dan Amerika.

Keberhasilan pengembangan jaringan usaha di Italia telah mempengaruhi beberapa negara di dalam pengembangan UMKM melalui kerjasama antar perusahaan. Pertama yang mempraktekkannya adalah Amerika Serikat, namun proyek yang paling sukses dan mungkin terbaik adalah "the Danish National Network Project", yang dikembangkan oleh Denmark tahun 1989.

Apa yang dapat dipetik dari pengalaman negara-negara maju dalam mengembangkan jaringan usaha adalah mengawalinya tidaklah mudah. Namun demikian, sekali berhasil akan mudah sekali untuk menularkannya.

Sebagai langkah awal yang perlu dilakukan adalah merubah kultur bisnis (changing business culture). Inilah yang tidak mudah dilakukan yaitu merubah budaya berbisnis. Bukan saja UMKM, usaha besarpun ada kecenderungan ingin melakukan monopoli dalam bisnisnya. Terlebih lagi kalau mereka betul-betul sudah menikmati hasil yang besar dan semakin besar dari kegiatan bisnis yang dilakukan. Adanya Undang-Undang Nomor 5 tahun 1999 tentang Larangan Praktek Monopoli dan Persaingan Tidak Sehat akan menjadi pembatas untuk mewujudkan persaingan bisnis yang lebih sehat. Undang-Undang ini akan menjadi salah satu aturan yang mendorong terjadinya kerjasama usaha antara pelaku usaha.

Guna lebih mempercepat proses terjadinya jaringan usaha antara UMKM dan antar UMKM dengan usaha besar, baik di dalam dan di luar negeri maka perlu ada media khusus untuk mengkampanyekan hal tersebut. Sebagaimana juga dilakukan negara-negara maju, proses 
untuk mendorong jaringan usaha harus dipromosikan lewat media cetak maupun elektronik. Melalui media inilah diinformasikan konsep jaringan usaha dan apa manfaatnya. Disamping itu juga perlu ada talk shows melalui televisi atau radio, presentasi pada asosiasi-asosiasi perdagangan, surat-menyurat langsung kepada UMKM.

Setelah sosialisasi tersebut berhasil dan telah tumbuh kesadaran para UMKM untuk melakukan kerjasama maka perlu dipikirkan mengenai pialangnya (brokers) atau makelarnya. Para pialang ini bisa dari kantor pemerintah, konsultan, pensiunan, atau sukarelawan pengusaha. Namun demikian akan lebih baik kalau ada layanan pengembangan bisnis (BDS, business development services) di tingkat pusat, propinsi, dan kabupaten/kota, baik milik pemerintah, swasta, ataupun semi pemerintah. Konsultan konsultan BDS ini sebaiknya juga mendapatkan pelatihan khusus mengenai pengembangan jaringan usaha. Di dalam pelatihan tersebut mereka diberikan studi kasus mengenai struktur dan fungsi jaringan, teknik berorganisasi, resolusi konflik, perencanaan strategi kelompok, dan pengembangan pasar. Disamping itu juga perlu diberikan kesempatan kerja lapangan untuk mencoba mempraktekkan teori melalui pengembangan jaringan rintisan.

\section{KESIMPULAN}

Menghadapi tantangan globalisasi, UMKM harus diberdayakan agar mampu bersaing dengan pelaku bisnis lainnya baik dari dalam maupun luar negeri-salah upaya penguatan daya saing UMKM adalah melalui pembentukan jaringan usaha (business networks). Di samping untuk penguatan daya saing, jaringan usaha juga bermanfaat untuk meningkatkan cakupan ekonomi, efisiensi, pengelolaan bisnis yang efisien, dan memperluas pangsa pasar, untuk mendorong tumbuh kembangkan jaringan usaha ini, sebagai langkah awal yang perlu dilakukan adalah merubah budaya bisnis (business culture). Setelah tumbuh kesadaran untuk melakukan kerjasama, maka perlu disiapkan para pialang (brokers) yang nantinya menyembatani pihak- pihak yang akan melakukan kerjasama usaha. Guna memberikan pengetahuan dan keterampilan bagi para pialang, maka pelatihan dengan praktek lapang harus menjadi pendukung upaya penguatan tersebut

\section{DAFTAR PUSTAKA}

Dipta, I. W. (2004). Membangun Jaringan Usaha Bagi Usaha Kecil dan Menengah.

Hendriyanto, A. (2015). Analisis pengaruh jaringan usaha dan inovasi terhadap kinerja umkm. Jurnal Ilmu Manajemen Dan Akuntansi Terapan (JIMAT), 6(1), 44-49.

Nurchim, N., \& Santoso, T. D. (2018). Induksi Teknologi pada UMKM Industri Kreatif: Pembangunan Infrastruktur Jaringan Internet. Khadimul Ummah, 2(1), 7-15. 
Putri, Z. E. (2018). PEMANFAATAN JARINGAN SOSIAL DALAM PENGEMBANGAN USAHA OLEH PELAKU UMKM (Studi Kasus: 8 Pelaku UMKM pada Sentra Makanan Rendang di Kelurahan Sungai Durian, Kecamatan Lamposi Tigo Nagari, Kota Payakumbuh). JSSH (Jurnal Sains Sosial dan Humaniora), 2(1), 1-16. 